\title{
Parsing Macpherson: the Last Rites of Locke the Possessive
}

\section{Individualist ${ }^{1}$}

\section{Introduction}

Great ideas, if they are to die, warrant a decent burial. C. B. Macpherson's Possessive Individualist reading of Locke is as brave, enticing and influential as perhaps any single interpretation in the history of exegesis. ${ }^{2}$ Yet it is wrong, root and branch. Serious challenges have been directed against it for almost a half-century. It is time the argument against the thesis was completed, and this view of Locke put to rest for good.

Why is this argument required now, fifty years after the publication of The Political Theory of Possessive Individualism, and long after its author is no longer around to defend it? There are two reasons. First, outside Lockean scholarship narrowly construed, Macpherson's influence remains powerful. To take just a couple of examples from the last twenty years, we might note James Penner's 1997 The Idea of Property in Law, which stands at the vanguard of contemporary legal property theory, and Mark Rose's 1993 Authors and Owners, which

\footnotetext{
${ }^{1}$ Hugh Breakey, Griffith University, Australia. Correspondence: h.breakey@griffith.edu.au. This is the pre-peer reviewed version of the following article: Breakey, H. (2013). Parsing Macpherson: The Last Rites of Locke the Possessive Individualist. Theoria. doi:10.1111/theo.12022, which has been published in final form at http://onlinelibrary.wiley.com/doi/10.1111/theo.12022/pdf

${ }^{2}$ C. B. Macpherson, The Political Theory of Possessive Individualism: Hobbes to Locke (London: Oxford University Press, 1962); all future citations of this work will be cited in the body of the text as, e.g., (PI:222).
} 
set the agenda for recent work on the history of intellectual property. ${ }^{3}$ Both these books, and many more like them, draw upon and reinforce the Macpherson reading of Locke. Within philosophy generally, Macpherson-esque accounts of Locke continue apace, recently with a 2006 offering in Philosophy paralleling Macpherson on all major points. ${ }^{4}$ And within the ranks of liberal political theory specifically, the posthumous publishing of John Rawls' Lectures on the History of Political Philosophy has reanimated key elements of the Possessive Individualist reading of Locke. Following a previous argument of Joshua Cohen's, Rawls styles his discussion as an achievement of one of Macpherson's main conclusions namely, that Locke endorsed an unambiguous class-state - without one of Macpherson's most controversial premises - namely, that the non-propertied are not subjects of Locke's initial social contract. ${ }^{5}$ But Rawls' debt runs even deeper than his explicit framing of the argument suggests - he unwittingly adopts the crucial Macpherson thesis that Lockean social contractors are legitimately in the business of filibustering and rent extraction. ${ }^{6}$ When so sympathetic and careful - not to say influential - a commentator as Rawls has granted his imprimatur to key aspects of Macpherson's Locke, then it is time the original argument was revisited.

${ }^{3}$ J. Penner, The Idea of Property in Law (Oxford: Clarendon, 1997), 192-200; Mark Rose, Authors and Owners: The Invention of Copyright (London: Harvard University Press, 1993), 5.

${ }^{4}$ Charles D. Tarlton, 'Does Chapter 5 of Locke's Second Treatise, “Of Property” Deconstruct Itself?' Philosophy 81 (2006) 611-30.

${ }^{5}$ John Rawls, Lectures on the History of Political Philosophy, ed. Samuel Freeman (London: Harvard University Press, 2007) 138-39; see also Joshua Cohen, 'Structure, Choice and Legitimacy: Locke's Theory of the State', Philosophy and Public Affairs 15 (1986) 301-24. ${ }^{6}$ Rawls, Lectures, 152. 
The second reason Macpherson's argument requires contemporary reassessment is its influence on Lockean scholarship itself. The worry is not that contemporary Lockean scholars endorse Macpherson's interpretation of Locke - they do not. ${ }^{7}$ The worry is that they nevertheless cannot help but follow the interpretative trails he blazed. Back in 1986 Richard Ashcraft, surveying the work of Berlin, Strauss and Parry, observed that it was 'striking how many of Macpherson's critics have accepted the basic dimensions of his argument' ${ }^{8}$ As we will see in what follows, little has changed in this regard. The theorists who continue to accept (what I will argue are) Macpherson's plainly mistaken readings of crucial passages of Locke - sometimes at considerable cost to their own positions - constitute a veritable who's who of Lockean scholarship; including, among others, John Dunn, James Tully, A. John Simmons, Neal Wood, Jeremy Waldron and (yes) Ashcraft himself.

All this might be granted, but even a sympathetic reader might yet wonder if anything more can be added to the already sizable literature on Locke qua Possessive Individualist. I think it can. There are, I submit, three ways of interrogating an interpretation such as Macpherson's. First, one can look to the many parts of Locke's corpus that Macpherson left untouched to search for pronouncements conflicting with his characterization. Since it is a striking feature of Macpherson's reading that it centrally employs just three texts, Locke's Second Treatise of Government, his 1691 Some Considerations of the Consequences of the Lowering of Interest and the Raising the Value of Money: in a letter sent to a Member of

\footnotetext{
${ }^{7}$ The scholarly trend is away from the fervently capitalist Locke: J. S. Maloy, 'The Aristotelianism of Locke's Politics', Journal of the History of Ideas 70 (2009) 235-57, 238.

${ }^{8}$ Richard Ashcraft, Revolutionary Politics and Locke's Two Treatises of Government (Princeton: Princeton University Press, 1986), 280.
} 
Parliament, ${ }^{9}$ and The Reasonableness of Christianity, ${ }^{10}$ most of the early critiques of Macpherson's exegesis gravitated in this direction. ${ }^{11}$ Second, a critic might turn to a discussion of Locke's historical and discursive context, considering, for example, the usage of words like 'property' and 'consent' in seventeenth century political theory, or of the wagerelations, property entitlements and institutions of democracy extant at that time, in order to argue that Macpherson's Locke was off-beam. This too, has proven a fertile field of criticism. ${ }^{12}$ Yet these methodologies have their limitations. Discussions of context and discursive tradition are important, but rarely definitive. And even if Locke did make arguments against the Possessive Individualist stance elsewhere - even elsewhere within the

\footnotetext{
${ }^{9}$ John Locke, Two Treatises of Government (New York: Hafner, 1947). All future citations to the Second Treatise will be made within the body of the text to section number, as, e.g., (ST§52); John Locke, Some Considerations of the Consequences of the Lowering of Interest
} and Raising the Value of Money, 10th ed., 10 vols., vol. 5, Works (London: Rivington, 1824). All future citations of this work will be made within the body of the text as, e.g., (C:25). ${ }^{10}$ John Locke, The Reasonableness of Christianity, 12th ed., 9 vols., vol. 6, Works (London: Rivington, 1824).

${ }^{11}$ The classic example remains Alan Ryan, 'Locke and the Dictatorship of the Bourgeoisie', Political Studies 13 (1965) 219-30.

${ }^{12}$ E.g. John Dunn, 'Democracy Unretrieved, or the Political Theory of Professor Macpherson', British Journal of Political Science 4 (1974) 489-99; James Tully, A Discourse on Property: John Locke and His Adversaries (Cambridge: Cambridge University Press, 1980); James Tully, An Approach to Political Philosophy: Locke in Contexts (Cambridge, 1993), 71-95; Jacob Viner, “"Possessive Individualism” as Original Sin', The Canadian Journal of Economics and Political Science 29 (1963) 548-59; Richard Boyd, 'The Calvinist Origins of Lockean Political Economy', History of Political Thought 23 (2002) 30-60. 
Second Treatise - the fact remains (it will be urged) that he nevertheless did say the things Macpherson said he did.

But there is a third mode of critique, which we might call refuting an argument on its own terms. On this method, one shows that the passages adduced as evidence by the interpreter given no more than their immediate context - did not mean what they were presented as meaning. I take it that systematically refuting an argument on its own terms is the most powerful critique that can be made of an interpretation. It shows that the exegesis was not even partially right - it was not even showing us one strand in the intellectual tapestry of a complex thinker. If an argument can be fully refuted on its own terms then the problem is not that the interpreter was cherry-picking the canon; it is that their pickings were not cherries at all.

In this essay I take up this mantle. I will contest Macpherson's thesis using only the passages he himself brings to bear as evidence as well as any immediate context (within two or three paragraphs) relevant to those passages. I will only refer to an overall text on a point where Macpherson himself refers to the entire text: for instance in his assertions of the overall 'emphasis of' or 'concepts in' a work. And operating wholly within that restricted purview, I will show the textual evidence offered by Macpherson in support of his keystone theses is misleading, misconstrued, misplaced or otherwise mistaken. And I will take this mode of critique into the very core of Macpherson's reading of Locke, where to this day his sharpest critics accept Macpherson's renderings - into those crucial passages of Locke's Chapter Five 'On Property'.

\section{Macpherson's four key theses: primary evidence}

Macpherson does not deny Locke held some genuinely egalitarian natural law commitments regarding equal rights and rationality. These postulates are acknowledged by Macpherson 
(PI:230-31) as present in both the Second Treatise (e.g. ST§4) and Locke's Essay Concerning Human Understanding. Macpherson's thesis is, however, that Locke also held other, conflicting commitments; he may have started with a 'beautiful set of natural rights', but he finished a possessive individualist. ${ }^{13}$ This last has four key features, and Macpherson offers an apparent wealth of textual support for each of them. The following summarizes each of Macpherson's four theses and his readings of Locke's text in support of each. While I will go on to reject all these readings, I will for expository ease in the following account describe Locke's passages wholly as Macpherson understood and deployed them. To avoid repetition, my treatment here of Macpherson's theses and his evidence is schematic - more detail will emerge when we proceed to the remaining sections.

Macpherson's first major thesis is that possessive individualists are 'infinite appropriators' in the sense that there are no significant limitations on their capacities to acquire land and capital at the expense of others (PI:206-20). In particular, Locke's 'sufficiency proviso' - the restriction that appropriators of land must leave 'enough and as good' for others - is overcome or transcended. Crucially, Locke asserts at ST§36 that the sufficiency proviso is removed with the introduction of money. Locke then attempts to justify this removal in several ways. First, Locke's view that people tacitly consent to money (ST§36, §47-§50) implies their consent to the inevitable consequences of a commercial economy. Those consequences, as Locke was well aware, include the development of wagelabor at necessarily subsistence levels (C:18, 20, 38). Second, Locke argues that by increasing the net total of wealth, appropriators actually benefit non-owners (ST§37). Third, Locke never thought 'enough and as good' was strictly required; he never uses this phrase when discussing periods after the advent of money, and this proviso was in any case only

${ }^{13}$ C. B. Macpherson, Democratic Theory: Essays in Retrieval (Oxford: Clarendon, 1973), 228. 
ever derivative of people's narrow natural law right to self-preservation (ST§26). Putting all this evidence together, Macpherson's arguments on the core of Locke's chapter on property have been adjudged - even by otherwise sharp critics - as arguably 'the most brilliant piece of analysis of any part of Locke's text yet produced'. ${ }^{14}$

Macpherson's second thesis is that Locke held that unfettered alienation of each person's property in labor is legitimate. Macpherson derives this thesis from Locke's repeated assertion (e.g. ST§28) that each person has 'property in his person' - including property in his labor (PI:216, 219). That full alienation is allowed is illustrated by Locke's careful distinction between slave and servant, where the former illegitimately alienates power over their life, while the latter only alienates the entirety of their labor. ${ }^{15}$ Furthermore, holding such ownership means the owner has no debt to society for his labor (PI:253), for Locke stresses that property can only be taken with the owner's consent (ST§138-40). Similarly, Locke's imposition of rights of inheritance to one's dependants does not mandate any duties inter vivos (ST§182-83).

Macpherson's third thesis is that Locke held the popular seventeenth century view that wage-laborers and the poor had different rights and rationality to the propertied classes (PI:222-26). Locke's views on the capacities of the laboring classes are made explicit in Considerations, where he assumes them to be largely incapable of political action, except

\footnotetext{
${ }^{14}$ John Dunn, The Political Thought of John Locke: An Historical Account of the Argument of the 'Two Treatises of Government' (London: Cambridge University Press, 1969), 215; See similarly Isaiah Berlin, ‘Hobbes, Locke and Professor Macpherson', Political Quarterly 35 (1964) 444-68, 461; Ryan, 'Dictatorship of the Bourgeoisie', 227; Neal Wood, John Locke and Agrarian Capitalism (Berkeley: University of Californian Press, 1984), 135.
${ }^{15}$ Macpherson on this point cites ST§83 (PI:219), but it is ST§85 that contains the relevant slave/servant comparison.


perhaps for illegitimate and violent insurrections (C:46). This view is supported by Locke's revealing discussion in The Reasonableness of Christianity where we find laborers unable to be led by reason to understand the Law of Nature, and therefore in need of simple Christian maxims.

Macpherson's fourth thesis is that the activities of possessive individualists necessarily create a class-divided society, where the proletarians are not only denied a stake in government decision-making (i.e. denied suffrage) but the government is not one to which they may be taken to have consented, and nor is there any requirement that they should have so consented (PI:198, 248-50). Granted, Locke did say the purpose of civil society was to protect every person's property in the broad sense of their life, liberties and goods (PI:198, 236). But Locke's final position is revealed in two crucial places. First, in the passages where he discusses the limitations on government powers, Locke requires only the propertied to have a voice (ST§138-39, §193). Second, Locke thinks all those within the territory of a state (including the native poor and laborers) must give tacit consent to be subject to the rules, but only those with estates can give full consent and be genuine members of the commonwealth (ST§119-22).

Not only does Macpherson thus provide a seeming surfeit of evidence for his signature claims, the four key theses themselves are logically inter-connected. For instance, the legitimacy of infinite appropriation (thesis one) results in a situation where some people have no opportunity to appropriate real property. This radical disparity in resources then forms the point of departure for Macpherson's account of the subsequent social contract - the compact to create political society that ushers in entrenched political class-divisions (thesis four).

Now it is my position that every single one of the references to Locke's text just outlined, when read just in the light of its immediate context, does not provide evidence for the thesis Macpherson draws from it. Fortunately for my purposes, several of the later pieces of 
evidence just noted, particularly as regards the final thesis of class-divided political society, have already been refuted on their own terms. I include at the closing of this paper a brief appendix detailing this prior work for the reader interested in ensuring completeness of argument. In what follows I take the attack to what has been widely thought to be the strongest part of Macpherson's case: the evidence for his first three key theses. Since these prior claims construct the intellectual scaffolding making his later conclusions tenable, even a reader unfamiliar with this Lockean scholarship should find the following argument probative. On the other hand, those familiar with the secondary literature I canvas in the Appendix will find, I submit, not one piece of Macpherson's evidence left standing upon completion.

\section{Macpherson's First Key Thesis}

Locke's 'sufficiency proviso' is his restriction on the capacity of individuals to naturally acquire land through their labor - a restriction created by other people's rights to engage productively with the world. One of the oft over-looked merits of Macpherson's reading ${ }^{16}$ is his awareness that the proviso can be asserted by Locke either in a positive way (respecting the rights of others to do things or have access to things) or negatively (restraining the extent of justified appropriation). As well as allowing Locke to put forward positive and negative expressions of the proviso, Macpherson also, though without naming them, distinguished two different renderings of Locke's proviso. Let's define a robust proviso as one that says (either positively) that people have a right to those things nature has provided such that they can improve and govern their lives or (negatively) that appropriators must leave 'enough and as good' for others. Let's stipulate a subsistence proviso as one that says (positively) that all

\footnotetext{
${ }^{16}$ Compare Jeremy Waldron, 'Enough and as Good Left for Others', The Philosophical
} Quarterly 29 (1979) 319-28. 
people have a right to labor for self-preservation or (negatively) that appropriators must leave enough goods for others to subsist. Macpherson famously argued Locke has the robust proviso being removed by people's consent to money. Let us consider the evidence.

\section{In ST§36 Locke explicitly states the overcoming of the robust proviso}

The most powerful form of evidence that Locke thought money was going to effect the removal of the robust proviso would be Locke saying just that. This occurs, Macpherson tells us, in ST§36 (PI:203). Several times in his ensuing argument Macpherson refers back to this, his key bridgehead where Locke is 'explicit' in the removal of the proviso (PI:211, 214). While I challenge Macpherson's reading of this crucial passage, it cannot be charged that he did not put the relevant evidence before the reader. He quotes Locke:

This I dare boldly affirm, That the same Rule of Propriety, (viz.) that every Man should have as much as he could make use of, would hold still in the world, without straitning any body; since there is Land enough in the World to suffice double the Inhabitants, had not the Invention of Money, and the tacit Agreement of Men to put a value on it, introduced (by Consent) larger Possessions, and a Right to them... ${ }^{17}$

Macpherson then says:

This is quite explicit. The natural law rule, which by its specific terms limited the amount anyone could appropriate so that everyone could have as much as he could use, does not now hold; it "would hold... had not... Money... introduced (by consent) larger Possessions, and a Right to them'. (PI:203)

Macpherson avers the evident conclusion; somehow the consent to money invalidated (or at least enervated) the robust proviso - Locke's Rule of Propriety that all should have what they

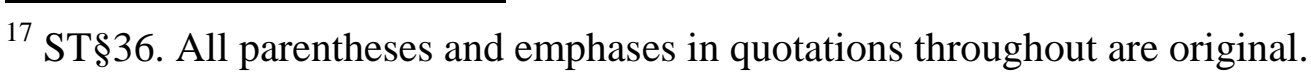


can use. While Macpherson's followers might be expected to embrace his reading of this section, ${ }^{18}$ it is difficult to find any contemporary scholar who rejects it. Waldron, Hundert and Simmons all accept Macpherson has the drift of this passage right, despite such acceptance creating, as they acknowledge, tensions or complexities in their accounts. ${ }^{19}$ Tully and Ashcraft likewise accept that ST§36 asserts the overcoming of the robust proviso, though both argue this ushers in a new consent-based property regime. ${ }^{20}$

But things are not so straightforward. Macpherson's recapitulation of Locke's sentence drops out the clause 'without straitning any body'. With this removed, it makes it look as if Locke is saying that the changes created by the introduction of money mean the Rule of Propriety cannot hold. But Locke says the converse of this: the Rule of Propriety would still hold without straitening anybody if money had not been invented. Since money has been invented, the natural implication is that someone is getting straitened somewhere, not that the Rule of Propriety is dissolved. Consider the following analogue: 'The storm would still be raging, without any harm to properties, had not the flood barriers broken'. The implication here is that because of the event where the flood barriers broke, properties are now being

${ }^{18}$ e.g. Tarlton, 'Deconstruct Itself', 114-16.

${ }^{19}$ Jeremy Waldron, God, Locke, and Equality (Cambridge, Cambridge University Press, 2002), 176, 183; E. Hundert, 'The Making of Homo Faber: John Locke between Ideology and History', Journal of the History of Ideas 33 (1972) 3-22, 12-13; A. John Simmons, The Lockean Theory of Rights (Princeton: Princeton University Press, 1992), 298-305, 317-18. Sympathies to Macpherson's rendering also appears in, e.g., Gordon Schochet, “'Guards and Fences" Property and Political Obligation in Locke's Political Thought', History of Political Thought 21 (2000) 365-89, 369; Wood, Agrarian Capitalism, 56, 135.

${ }^{20}$ Tully, Discourse, 130, 152-53, 165; Ashcraft, Revolutionary Politics, 137-39. 
harmed. It would clearly be mistaken to re-characterize the sentence as: 'The storm would still be raging... had not the flood barriers broken'.

While I think that this is the most plausible reading of Locke's claim, it might be objected that there are subtleties here requiring careful exploration. For Macpherson's reasoning may have been as follows: Locke is telling us that the introduction of money means the Rule of Propriety, if it still holds, will straiten someone. As such, Locke's disjunctive conclusion is that either the Rule of Propriety no longer holds, or that someone is being straitened. ${ }^{21}$ If that's right, then the analogue I presented above is misleading. Because the flood barriers breaking could not possibly halt the storm, that sentence must be telling us that properties are being harmed. A better analogue - it may be urged - would be one where the event in question (the flood barriers breaking) could potentially impact on either of the two prior factors (the storm and the harm to properties). A more apt example might be: 'The demonstration would still be happening, without any violence or rioting, had not the police physically engaged the demonstrators.' The meaning of this sentence is ambiguous. Have the police stopped the demonstration? Or have they precipitated violence and rioting? It seems to me that the structure of the sentence implies the latter, but it must be admitted that - as a matter of strict logic - either conclusion is possible.

If we take the view that Locke's sentence implies a disjunctive conclusion, ambiguous between the consent to money causing straitening or dissolving the Rule of Propriety, then much will turn on how we understand the transitive verb 'straiten'. If we take this term to ${ }^{21}$ Here is the formal logical rendering. Stipulate $\mathrm{M}=$ Introduction of Money; RP = Rule of Propriety; $\mathrm{S}=$ Straitening someone. Macpherson renders the argument as: Premise 1: If M, then $\sim$ RP. Premise 2: M. Logically valid conclusion: $\sim$ RP. With the clause re-inserted the argument is: Premise 1: If M, then $\sim(\mathrm{RP} \& \sim \mathrm{S})$. Premise 2: M. Logically valid conclusion: $\sim(\mathrm{RP} \& \sim \mathrm{S})$. That is, either $\mathrm{RP}$ is false or $\mathrm{S}$ is true. 
mean 'impoverish' then it is not implausible to think Locke will reject impoverishment, and so must dissolve the Rule of Propriety, justifying Macpherson's position. On the other hand, if we understand 'straiten' to mean 'narrow', 'confine' or 'limit in freedom and scope,22 then we will think that Locke is upholding the Rule of Propriety, and telling us that this rule is now limiting the freedom of some (or all) people. This, after all, would not be a surprise. Limiting freedoms is just what rules do - it is what makes them rules.

The immediate context of Locke's quote suggests this latter reading. Locke in ST§36 is telling us that before the use of money, people's acquisitions through their labours could not possibly infract on others' capacities to find room to work or plant their crops. Pre-money, no-one could actually have any motivation to breach the Rule of Propriety, because there was nothing to gain from taking more land than would allow one to produce the requirements of one's own family. But with the introduction of money, and the capacity to non-wastefully store one's produce (by trading for gold), the resources a person can gainfully use are greatly expanded. They can now benefit by taking more land for themselves. At this point, then, the Rule of Propriety requiring that each person should have what s/he can use becomes for the first time a genuine constraint on appropriation. It was never previously a constraint, for so as long as no-one wasted God's largess, there was no motivation for violating the Rule by taking too much. Only with the arrival of money did the Rule of Propriety limit the previous freedom of - straiten - budding appropriators from taking as much as they could possibly use. This rendering of Locke's sentence thus follows naturally and logically from the discussion preceding it. Macpherson's rendering, in comparison, has Locke suddenly announcing, with no previous argumentation, the dissolution of what previously appeared to be an important moral precept. Macpherson's rendering also carries the perverse consequence

\footnotetext{
22 'Limit in freedom and scope' is the older definition: see http://www.merriam$\underline{\text { webster.com/dictionary/straitened }}$
} 
that the Rule of Propriety (what I earlier termed the robust proviso) never actually constrained anyone; before the advent of money no one had any justifiable (non-wasteful) reason to use more than their share of land - and after the advent of money the Rule of Propriety has been dissolved or transcended. As such, it is perplexing why Locke ever introduced it.

But perhaps despite all this the reader still worries that, given we are speaking of economic issues, the intuitive reading of 'straiten' is 'impoverish', and that this tells in favor of Macpherson's reading. If so, such doubts can be allayed. Fortunately for our exegetical purposes, Locke uses the very term in question earlier in the same paragraph, speaking of the pre-money:

first ages of the world, when men were more in danger to be lost, by wandering from their company, in the then vast wilderness of the earth, than to be straitened for want of room to plant in. (ST§36)

Here the term's meaning is unambiguously to 'confine' or 'limit freedom'.

In all, we have compelling reasons to doubt Macpherson's rendering of ST§36. With the 'without straitening anyone' clause re-inserted, Macpherson's reading becomes at best questionable. When reference is made to the immediately preceding context it becomes unlikely. Its last vestiges of plausibility are stripped when we consider Locke's immediately prior use of the term 'straiten'. Ultimately, the natural reading of the passage is the exact opposite of Macpherson's assertion. Far from announcing the dissolution of the Rule of Propriety and the robust proviso, ST§36 is announcing that for the first time it is a genuine constraint on appropriation.

\section{Locke justifies the removal of the robust proviso by consent to money}

The significance to Macpherson's overall interpretation of his mis-reading of ST§36 is difficult to exaggerate. Macpherson himself admits that in the early editions of the Treatise 
Locke made no specific argument for the dissolution of the robust proviso (PI:211). It was only the alleged ironclad fact of ST§36 leaving 'no doubt' about the overcoming of the proviso that licensed Macpherson to speculate on how Locke might have justified this event (PI:211). The speculation runs thus:

His chain of thought seems to have been that the automatic consequence of the introduction of money is the development of a commercial economy, hence the creation of markets for the produce of land hitherto valueless, hence the appropriation of land not hitherto worth appropriating. And by implication, consent to the use of money is consent to the consequences. Hence an individual is justified in appropriating land even when it does not leave enough and as good for others. (PI:211)

The first problem with Macpherson's imputation here is the 'hence' in the last sentence. We have not as yet been given any evidence to believe Locke thought the consequences of consenting to money must involve people being left without their robust proviso entitlements. But such evidence is perhaps not so far away. In a matter of pages Macpherson moves to consider Locke's view on the naturalness of wage labour in the state of nature. Here Macpherson draws on Locke's Considerations to argue that Locke, 'assumed as self-evident that of necessity wages are normally at a bare subsistence level, and that the wage laborer has no other property than his labor' (PI:216). Several commentators otherwise critical of Macpherson accept the use of Considerations as evidence of Locke's acceptance of the inevitably harsh consequences precipitated by the introduction of money. ${ }^{23}$

The problems with this use of the Considerations, however, are substantial. To begin, Locke in Considerations never says that the laborer's subsistence-level existence is inevitable

\footnotetext{
${ }^{23}$ Hundert, 'Homo Faber', 6-7; Wood, Agrarian Capitalism, 43-5, 75; Ian Shapiro, The Evolution of Rights in Liberal Theory (Cambridge: Cambridge University Press, 1986), 127.
} 
in the sense required by Macpherson's argument. To be sure, Locke takes the laborer's largely 'hand to mouth' existence as an undeniable feature of his contemporary context. It would have been obtuse of him to deny it. But there is nothing in his language to suggest he felt their situation to be necessary - he uses terms like 'generally' and 'seldom', and mentions situations where laborers impose their rate on landholders (C:19). But even if there was such language, it would be gratuitous to link talk of necessitousness to the workings of a market economy in particular, as distinct from any number of other grim political realities of Locke's time. Without such inevitability, and without its manifest link to market economies, there is no impediment to supposing that consent to money is not an endorsement of subsistence wages. A non-land-owning person could consistently agree to the use of money and wage-labor without that implying dissolution of their entitlements under the robust proviso. In all, Macpherson's referenced passages in Considerations (C:18, 20, 38) contain no more than Locke's asserting the harsh conditions of the laborers of his time - usually in order to argue they should not have their situation further worsened by the state's ill-judged monetary policy. Granted, Locke does not explicitly condemn the injustice of their condition, but even Macpherson proves unwilling (as Shapiro and Wood later do $\operatorname{not}^{24}$ ) to parlay offhand remarks about descriptive facts in letters to public officials into evidence regarding the deepest normative postulates of a thinker. ${ }^{25}$

Even supposing we had a wealth of evidence, from Considerations and elsewhere, that Locke thought market economies inevitably impoverish laborers, there still would be grave problems with the 'chain of thought' Macpherson envisages. For this 'consent to brutal consequences of money' argument is a poor line of reasoning to attribute to Locke. This is

\footnotetext{
${ }^{24}$ Ibid.; Wood, Agrarian Capitalism, 43-5, 75.

${ }^{25}$ See, generally, Dunn, Political Thought, 238-41.
} 
admitted even by those who make the attribution; Waldron evaluates it as 'one of the worst arguments in the Second Treatise, ${ }^{26}$

Why is the argument so poor? In his discussion of the origin of money Locke consistently speaks as if the people doing the consenting are the ones agreeing to use money (ST§46-§50). But the ones getting worsened by this decision (as Macpherson will have it) are those losing the capacity to appropriate land for themselves. We have no evidence these two groups are co-extensive and every reason to believe they wouldn't be. Of course, with no further land to appropriate, the property-less may subsequently be forced into wage-labor, but this hardly can be taken as consent for the fact that they couldn't appropriate in the first place. The argument also fits poorly into Locke's chapter on property. Why all the emphasis on labor and non-worsening if Locke's ideological purpose was always going to require a parlous appeal to an unlikely and unsupported act of consent $?^{27}$ Even as he imputes this position to Locke, Tarlton observes: 'If Locke had all along possessed and presented evidence of this consenting to money and to an inequality of property, he might have saved himself the trouble of most of what is contained in chapter $5 .{ }^{28}$ Just so. One might think that if we are imputing a line of thought to a thinker that renders otiose the vast majority of his actual argument, then something has gone wrong somewhere.

Is there a better interpretation of Locke's consent to money? Of course there is. Locke is explicit about it. Money is introduced into the world with the decision of a producer to

${ }^{26}$ Waldron, God, Locke, and Equality, 176; see also Simmons, Lockean Theory of Rights, 317.

${ }^{27}$ Particularly given that Locke's political theory, in order to reply adequately to Robert Filmer's prior arguments, had to avoid just such an appeal. See Schochet, 'Guards and Fences', 382-83.

${ }^{28}$ Tarlton, 'Deconstruct Itself', 120. 
exchange useful produce for metal, sparkling pebbles or diamonds (ST§46). That consent, made en masse by enough persons at enough times, gives value to money. Once this occurs, money allows excess produce not to spoil - for perishable surpluses can be traded for durable metals. At the end of his analysis Locke repeats that the consent was significant purely because it found a way around this problem of spoilation (ST§50). The origin of money described in Locke's economic writings is similar, though there the emphasis changes. In Considerations, Locke argues money developed out of pledges - bills, bonds and notes of debt - where the pledger is willing for the pledge to be transferred to others. Money, Locke says, is a standardized, reliable, transferable pledge; metals having as money 'no other value, but as pledges to procure, what one wants or desires... ${ }^{29}$ While in the Second Treatise we have the consent to trade produce for metals, in the Considerations we have consent in the form of a person making a standard, transferable pledge. These are the only types of consent discussed in the entirety of Locke's two actual discussions of the genesis of money.

At this point our exegetical alternatives are these: we can impute an un-expressed line of thought to Locke that is on the one hand poorly reasoned on its own terms and on the other aligns disastrously with the rest of his argument in $\mathrm{Ch} . \mathrm{V}$, in order to sustain an interpretation of a single sentence that (as we saw in the foregoing section) is at best questionable and at worst expresses exactly the opposite of what Locke himself was saying. Or we can accept that the consent to money involves no more than what Locke says it does, and that the robust proviso is untouched.

\footnotetext{
${ }^{29} \mathrm{C}: 17$. Since Macpherson refers to the 'concept of money' Locke used in Considerations (claiming its characteristic function was to serve as capital: PI:206-7) its discussion is within my purview. Note in passing this quote is a direct contradiction of Macpherson's claim.
} 


\section{Locke's productivity argument of ST§37}

Macpherson suggests Locke himself might have been aware of the limitations of his (putative) 'consent to brutal consequences of money' argument:

While a case for the removal of the sufficiency limitation can be made out by inference this way, Locke apparently felt that a more direct argument was needed, for in a revision of the third edition of the Treatises he added a new argument following the first sentence of sect. 37 (PI:211).

Many commentators accept Macpherson's characterization of ST $\S 37$ as the 'centre of the demolition' of the robust proviso. ${ }^{30}$ But in the context of his argument, Macpherson's adverting to the first sentence of ST§37 approaches sheer mischievousness. The sentence begins:

This is certain, that in the beginning, before the desire of having more than man needed had altered the intrinsic value of things, which depends only on their usefulness to the life of man; or had agreed, that a little piece of yellow metal, which would keep without wasting or decay, should be worth a great piece of flesh...

That is, the sentence unambiguously announces that Locke is now speaking of a time prior to the introduction of money. Locke is returning from his fleeting mention of money in ST§36 to his main task of showing the legitimacy of pre-money property acquisition. This assertion at the beginning of ST§37 is ratified by the final clause of ST§36 where Locke tells us he is putting off his discussion of consent to money to a later point ('I shall by and by shew more at large'), i.e. to the lengthy discussion beginning at ST§46. In all, if Locke wanted his

\footnotetext{
${ }^{30}$ Tarlton, 'Deconstruct Itself' 116; similarly John Dunn, 'Interpretation of Locke's Political Theory', Political Studies 16 (1968) 68-87, 74; Thomas Pogge, Realizing Rawls (London: Cornell University Press, 1989), 58.
} 
argument of ST§37 to apply to consent-to-money he could scarcely have put it in a more confused place.

But perhaps, it might be objected, Macpherson's mistake here was merely to imply that ST§37 had relevance for the 'consent-to-money’ argument (PI:211). To the contrary, perhaps ST§37 works as a standalone demolition of the robust proviso. Before proceeding on this hypothesis, note how thin this leaves the evidence for the overcoming of the proviso through consent to money. Even Macpherson admits Locke did not argue for this thesis initially (PI:211). Now we find Locke's later alleged argument justifying the event is not even speaking of the relevant period at all.

Proceeding now on the basis that Locke's argument of ST§37 is a standalone dissolution of the robust proviso, its placement is still mystifying. Why deploy an argument in the express context of a surfeit of available land when its alleged central application is to justify appropriation in the face of land scarcity? Why make the insertion at ST§37 rather than, say, ST§50?

The answer to this question need not detain us, for the substance of the argument is in any case not to Macpherson's purpose. Locke's premise in ST§37 is that the productivity of farmed land is (at least) ten times greater than land left in common. If it takes one hundred acres of unappropriated commons-land to create enough for one person's 'conveniences of life', then it takes only ten 'inclosed and cultivated' acres to create the same produce. Why does this difference in productivity matter? Macpherson tells us it matters because 'the greater productivity of the appropriated land more than makes up for the lack of land available for others' (PI:212). That is, perhaps through some 'trickle down' mechanism, enough of the increased productivity of the appropriated land benefits non-appropriators such that they are, in sum, better off than before. If this direct relationship between taking and benefit-to-others is true for the appropriating of any one acre, then it remains true (for the 
same reason) for the appropriating of any amount of acres. In Macpherson's hands, Locke attempted a justification of unlimited appropriation.

But this is not Locke's argument. ${ }^{31}$ For Locke in ST§37, the person who previously produced their 'conveniences of life' from one hundred acres left as commons can now do so from ten appropriated acres. This eases the situation of all others by freeing up ninety acres of land - land they may now use to produce their own conveniences. Observe, however, that if the first person instead appropriates twenty acres (to attain luxury, say) then they have only 'given' eighty acres to mankind. And this inverse relationship between size and benefit-toothers continues for still-greater appropriations, until land-grabs become unqualified takings. In Locke's argument, the more land beyond their initial share that one individual takes, the less others gain from their appropriation. Contra Macpherson, ST§37 is an argument justifying only a person's limited appropriation - and thus its placement in the pre-money context makes perfect sense.

\section{Locke's replacement of the robust proviso with the subsistence proviso}

But perhaps Locke never really advanced the robust proviso in the first place (PI:213-14). Rather than intending that appropriators should be restrained by the robust proviso, Macpherson argues that all Locke required was the subsistence proviso: that appropriators ensure others can work for their survival. (One might wonder how Macpherson can at once hold that Locke explicitly removed the robust proviso and that he never held it.) Macpherson offers two arguments to this end: first, the robust proviso was derivative of the more fundamental subsistence proviso. Second, Locke does not refer to the robust proviso after the advent of money, suggesting it was no longer applicable after that point.

\footnotetext{
${ }^{31}$ Waldron, 'Enough and as Good', 323.
} 
Macpherson's first argument warrants careful consideration. The capacity to preserve oneself, and to preserve humanity in general, looms large in the Treatises, and whatever else the proviso is doing it is certainly responding to this most central injunction of God and Natural Law. But there are nevertheless fatal problems.

In Macpherson's supporting reference to ST§26 Locke does indeed speak of the significance of subsistence and the 'support of life'. But there - as indeed throughout his argument - Locke speaks in more expansive terms of God's intentions regarding human use of the world: it being for 'the best advantage of life, and convenience', the 'support and comfort of their being' and so on. So ST\$26 is hardly evidence of the narrowness of the initial entitlement from which we derive the proviso. Quite the contrary; if this broad entitlement to labor for convenience and comfort is to be protected, the robust proviso is required. Furthermore, in ST§26 Locke doesn't use the aforementioned entitlement to derive the proviso - but to derive the right of property itself. Now Macpherson might be thinking the same entitlement that creates property is also limiting it (as would be ratified by ST§31). But he can't have it both ways. If subsistence is all that is being legitimated in ST§26 then appropriation cannot extend to producing conveniences, let alone to producing capital for its own sake. If more than subsistence is being legitimated, then the proviso requiring we allow others their legitimate uses becomes increasingly robust. On either construal, Macpherson's argument falters.

But the true status of Macpherson's position becomes clear only when we consider his larger argument. Macpherson accepts that Locke began (e.g. in ST§4) with generous natural rights for every single person as a basic postulate. He further accepts that Locke's 'first natural right' included entitlements to the means of creating not just subsistence but 
'conveniences'. ${ }^{32}$ Macpherson's thesis is that these original postulates were overturned with the dissolution of the robust proviso:

Locke, after beginning with a beautiful set of natural rights, which are said to be effectively sanctioned (as well as limited) by natural law, then goes on to override one of the most important limits (the limit on infinite appropriation), thus removing the equality of natural rights... ${ }^{33}$

So it is clear to Macpherson that Locke's generous natural rights, a) are protected by the robust proviso, and, b) are not protected by the subsistence proviso. How then does Macpherson manage to convince himself that the proviso is not derived from those initial natural rights $?^{34}$ We are faced with a case where a commentator accepts that a theorist holds unambiguously asserted postulate $\varphi$, accepts that from $\varphi$ it is possible to validly derive $\varepsilon$, accepts that the theorist repeatedly asserted $\varepsilon$, but then asserts that the theorist did not really mean to assert $\varepsilon$, because the ground for $\varepsilon$ was actually not $\varphi$ but some other premise entirely, a premise that in fact does not manage to ground $\varepsilon$, but only a much weaker claim. And then, more striking again, not only does the commentator deny the theorist ever held $\varepsilon$, but in order to explain his or her putative failure to hold $\varepsilon$ the commentator moves backwards to impute new unspoken postulates to the theorist that are directly contradictory with the originally admitted postulate $\varphi$. This really will not do.

Macpherson's final claim - that Locke never uses the robust proviso in his discussion of money-economies - is just false. Allowing that Macpherson may be forgiven for not recognizing ST§36 as a counter-example, because of his questionable reading of that passage

\footnotetext{
${ }^{32}$ Macpherson, Democratic Theory, 229.

${ }^{33}$ Ibid., 228.

${ }^{34}$ This derivation is performed in, e.g., Simmons, Lockean Theory of Rights, 290-94.
} 
discussed above, and putting aside marginal cases like ST§35 and ST§50, there is ST§46.

Here Locke says that to the good things nature has provided 'every one had a right (as hath been said) to as much as he could use'. This is the robust proviso: it is almost exactly the words Locke uses for the Rule of Propriety that in ST§36 Macpherson tried to argue was overturned by the introduction of money. Locke continues on in this passage to argue that a person bartering away food for 'a piece of metal' does not invade the right of others. This reference to metal introduces money (ST§47). Thus, contrary to Macpherson's assertion, we have both the robust proviso and the use of money in the same passage. Indeed, we have the clear implication that the consent to money is not invading the rights granted by the robust Rule of Propriety. This is, of course, just as we would expect, given the above discussion of ST§36.

In sum, none of Macpherson's cited evidence gives us the slightest reason to believe Locke in any way departed from the generous equal rights from which he began. Quite the contrary: the robust proviso stands firm.

\section{Macpherson's Second Key Thesis}

Macpherson's core description of the possessive individualist is of a person who is deemed the proprietor of their person and their labor, by which he connotes that they have full alienability over their labor, and owe no duties to society. Macpherson's evidence for the first claim has already been dealt with in the secondary literature, ${ }^{35}$ it is the latter commanding our attention here.

Macpherson's main evidence that Lockean property-owners have no duties to others is located in ST§138. In that passage Locke asserts that a person's property and goods cannot be taken without their consent. Macpherson sees this as 'a clear statement of an extreme

\footnotetext{
${ }^{35}$ See Appendix below, text to n. 41.
} 
individualist position' (PI:253). He is then immediately confronted with Locke's majoritarian position of ST§140:

it is fit every one who enjoys his share of the protection, should pay out of his estate his proportion for the maintenance of it. But still it must be with his own consent, i.e. the consent of the majority, giving it either by themselves, or their representatives chosen by them...

This, observes Macpherson, 'seems difficult to reconcile with the strong individualist position Locke has just asserted' (PI:253). Macpherson inventively solves the mystery by deploying possessive individualist thesis number four. Locke must have meant the majority to be a majority of property-holders acting on their class interest, for 'on this assumption, and only on this assumption, is it consistent to equate (rational) individual and (rational) majority consent' (PI: 254).

But Macpherson is solving a mystery of his own devising. What Locke stipulates about consent (viz. majority-decision) in ST§140 tells us what he meant by consent to takings both in that passage and the preceding two paragraphs. Even if there were no further evidence ready to hand, Macpherson's interpretation amounts to this: the reader understands a term at one point in a way that seems right to him, and then when the term is defined shortly afterwards (having been continuously used in the meantime) thinks he is owed an explanation of how to reconcile the definition provided with what he knows was meant in the earlier usage - instead of reconsidering what that earlier usage must have meant. As an interpretative strategy this bludgeoning of the capitalist rabbit into the majoritarian hat is not just uncharitable but willfully perverse. In any case, ST§138 itself speaks of how the property-holder's entitlements regarding consent are likely to be assured in a country with variable assemblies, as the members at one moment find themselves to be - upon dissolution of the assembly - subjects of their laws the next. Thus in the putative statement of 'extreme 
individualism' we already have the plain implication that 'consent' is understood as representative and procedural justice - an implication explicitly ratified within two paragraphs. ST§138 never was a statement of an extreme individualist position because Locke stipulates that the consent there requires only majority decision-making.

Macpherson's only remaining evidence for the claim that property-holders have no duties to others is this rendering of ST§182-83:

That Locke's law of nature gives a man's wife and children a claim on his estate in the event of his death or his subjection by conquest does not seem to be a limit on his disposal of it while he is a free agent. (PI:219)

This is just false. Locke's argument in these passages is that the conqueror of an illicit aggressor cannot have a right to the goods required by the aggressor's children for their preservation because those goods are not the aggressor's to forfeit (ST§183). Such goods 'continue' to 'belong' to the children (ST§182) who held 'a right to be maintained' out of their father's labor or substance (ST§183). Such prior rights are a manifest limitation on inter vivos disposal of estates. Moreover, the 'law of nature' Macpherson mentions - that 'all, as much as may be, should be preserved' (ST§183) - is plainly decreeing these ongoing rights and thus creating exactly the limitation Macpherson incredibly denies. And even if Macpherson is somehow envisaging the presence of the child's right might somehow exist without corollary duties of the parent, he could have easily resolved this confusion by reference to the sole passage from Locke's chapter 'Of Paternal Power' he cites (PI:244). In ST§60 Locke speaks of the 'duty, which God and nature has laid on man, as well as other creatures, to preserve their offspring'. The remains of that chapter continue Locke's remorseless ‘familialisation' of property (to use Tully's apt phrase ${ }^{36}$ ).

${ }^{36}$ Tully, Discourse, 133. 
In all, the majoritarian nature of Locke's property's boundaries (ST§138-40) leaves substantial scope for the duties of property-holders - scope Locke explicitly fills with, among others, familial obligations (ST§60, §182-83).

\section{Macpherson's Third Key Thesis}

The final argument to be assessed is Macpherson's position that Locke believed - as an unargued assumption shared by his readers - that members of the laboring class were not rational in the sense of being able to be guided in matters of morality by their rationality. They were not so because the exacting conditions under which they labored left no space for higher thoughts.

Macpherson's characterization of The Reasonableness of Christianity on this point has been substantially critiqued; ${ }^{37}$ here I will focus on his equally troubling re-imagining of the

Considerations. Macpherson builds his (and in his footsteps, Hundert and Wood build their ${ }^{38}$ ) case around a passage where Locke asserts that the laborer's share of the national income: ...being seldom more than a bare subsistence, never allows that body of men time or opportunity to raise their thoughts above that, or struggle with the richer for theirs, (as one common interest,) unless when some common and great distress, uniting them in one universal ferment, makes them forget respect, and emboldens them to carve to their wants with armed force: and then sometimes they break in upon the rich, and sweep all like a deluge. But this rarely happens but in the maladministration of neglected, or mis-managed government... (C:46)

Now Macpherson:

\footnotetext{
${ }^{37}$ See Appendix below at text to nn. 42-44.

${ }^{38}$ Hundert, 'Homo Faber', 6-7; Wood, Agrarian Capitalism, 43-5, 75.
} 
It would be hard to say which part of these remarks is the most revealing. There is the assumption that the laborers are normally kept too low to be able to think or act politically. There is the assumption that on the rare occasions when they do raise their thoughts above bare subsistence, the only kind of political action they will take is armed insurrection. There is the assumption that maladministration consists not of leaving the poor at bare subsistence, but of allowing such unusual distress to occur as will unite them in armed revolt. And there is the conviction that such revolt is improper, an offence against the respect they owe to their betters. (PI:223-24)

It would be hard to say which part of these remarks is the most revealing. Ashcraft notes the context of this passage is important to grasping its meaning, but the brevity of his subsequent treatment is, I think, far too generous to Macpherson. ${ }^{39}$ Locke is here considering what would happen if one third of the money currently employed in trade were 'locked up, or gone out of England' (C:46). He suggests all three relevant groups (monied/merchants, landowners, and laborers) would be jealous and suspicious of others, and that they will wish to employ their powers to retrieve their losses. Locke continues: 'But this is but scrambling amongst our selves, and helps no more against our want, than the pulling of a short coverlet will, amongst children, that lie together, preserve them all from the cold. Some will starve, unless the father of the family provide better, and enlarge the scanty covering' (C:46). Locke thinks this pointless and ill-conceived struggle is normally between the landowners and the merchants. Macpherson's quoted passage is the explanation of why the laborer is not liable to take part in the struggle.

Thus: I) Locke is only talking about a type of useless struggle where classes use their $d e$ facto powers to try and illicitly take from others who they mistakenly think are responsible

${ }^{39}$ Ashcraft, Revolutionary Politics, 268. 
for their losses. For the laboring class, such illicit action must come in the form of armed insurrection. The landowners will instead try to make laws to recoup their losses from the merchants. Clearly, seventeenth century laborers could not subvert justice that way. Locke is no more saying that the only impact on policy possible by laborers in general is armed insurrection than he is saying the only impact on policy possible by the landowners in general is illicit grasping from merchants.

II) Locke simply does not say that maladministration only involves allowing 'unusual distress'. Even if there were no further evidence to bring to bear, Macpherson's imputation is gratuitous. But the immediate context belies Macpherson's reading. Locke's scene-setting analogy to the father that must provide better for the cold, starving children scrabbling pointlessly over the tiny sheet carries the clear implication that the role of government is to make sure there is enough to go around in good times and bad. It is all to Locke's purpose if we read the passage as an indictment of neglectful governments clumsily over-regulating monetary policy in such a way as to impoverish the laborers. Indeed, the 'sheet' metaphor creates a prism in which to view Locke's overall mercantilism in Considerations (see PI:205). Increasing national wealth enlarges the sheet for all the children, keeping them better protected from vicissitudes, and upholding the peace by allowing them to have better methods of improving and securing their conditions than useless infighting.

Finally, III) there is indeed a clear intimation that the insurrection is improper (notwithstanding Locke's barbed reference to the state's maladministration). But given the immediate context of the argument, Locke had reason for this judgment. The laborers - like the landowners - have mistaken who is responsible for their loss. Their actions - like the landowners - do not respect procedural and democratic justice: 'the cause is mistaken, and the remedy too' (C:46). As well as suppressing this context, Macpherson - just as he does in his discussion of The Reasonableness of Christianity - drops out all mention of Locke's 
censure of the rich to make it look as if the poor are the object of special opprobrium. Set in its proper context however, this passage from Considerations provides no evidence for the ‘differential rationality’ of classes.

\section{Conclusion}

In an early review of Macpherson's book, Isaiah Berlin complained that it was a tedious business defending traditional interpretations against new ones. ${ }^{40}$ Perhaps so; but history has shown it is also a necessary one. Even setting aside those occasions where Macpherson simply reads Locke's words incorrectly (ST§36, §37), his evidence consists of case after case of stunning interpretive liberties: of misrepresentation as to the placement of a quoted passage (ST§37), of gratuitously imputing unasserted premises that do not support Locke's conclusions at the expense of asserted premises that do (ST§4, §26), of dropping out caustic discussions of landowners and merchants to make Locke's deprecations about laborers appear sinister (C:46), of willfully resisting reading a term in the way the author immediately defines (ST§:138-40), of misleading representations of the nature and immediate context of cited passages (ST§26, C:18, 20, 38, 46), and of plainly false characterizations of Locke's assertions (ST§182-83). All these devastating misrepresentations combine to leave the reader with a figure that is almost, but not completely, quite unlike John Locke.

In conclusion, nothing more remains to be said but to remind the reader of the status of the above evidence in Macpherson's overall argument. I have argued (I hope persuasively and not too tediously) that the passages cited provide no evidence for any of Macpherson's key theses about Locke. But even readers who have different evaluations of Macpherson's interpretive strategies should bear in mind that, for Macpherson, the passages we have considered are not even where ambiguities are supposed to lie. The ambiguities and

\footnotetext{
${ }^{40}$ Berlin, 'Professor Macpherson', 467.
} 
contradictions are supposed to arise when we turn from these clear assertions of possessive individualism to Locke's other conflicting statements. It is on the basis of the evidence we have surveyed - a handful of passages scattered across two lengthy works - that we are asked to overturn what Macpherson himself admits are Locke's explicit egalitarian fundaments. But far from the evidence being up to that task, I have argued it cannot establish even a prima facie case irrespective of any consideration of conflicting evidence.

Ultimately, all the evidence Macpherson provides for his radical capitalist reading of Locke can be dismantled purely on its own terms. The thesis warrants burial.

\section{Appendix}

I take the following four discrete pieces of Macpherson's evidence to have been successfully rebutted by the prior literature noted below. In combination with the foregoing argument, all of the passages adduced as evidence for Macpherson's four key theses can be judged as refuted on their own terms.

First, with regard to Macpherson's second thesis of the unfettered alienability of persons and their labor, ST§28 and ST§85 do not imply the complete alienability of liberty and labor. ${ }^{41}$ In particular, ST $\$ 85$ does not distinguish slaves from servants purely on the basis of the former forfeiting their right to life, but also on several other grounds, including concerns with liberty, property and membership in civil society.

Second, with regard to Macpherson's third thesis of differential rationality of the wagelaborers, from the first reviews, ${ }^{42}$ to the lengthy responses, ${ }^{43}$ to the most recent critiques, ${ }^{44}$

\footnotetext{
${ }^{41}$ Simmons, Lockean Theory of Rights, 262; Tully, Discourse, 136-46.

${ }^{42}$ Ryan, 'Dictatorship of the Bourgeoisie', 223.

${ }^{43}$ Richard Ashcraft, Locke's Two Treatises of Government (London: Allen and Unwin,
} 1987), 152-59; Dunn, Political Thought, 234-35. 
commentators argued that, far from declaring the irrationality of the laboring classes, The Reasonableness of Christianity relentlessly averred precisely the opposite. With an air of disbelief at Macpherson's temerity, critics complained that the laborer's path to moral and theological truth - through the Scriptures - was for Locke the only route available.

Third, with regard to Macpherson's fourth thesis of class-divided political society, commentators have responded to Macpherson's attempt to present ST§138-40 as evidence that only estate-holders are full members of civil society. It has been shown, a) that the key sentences in these passages can be coherently read as referring to Locke's broad notion of property as life, liberty and goods, ${ }^{45}$ and, b) that even if Macpherson is right that 'property' connotes only physical property in these passages, this still does not imply civil society is only for the bourgeois. ${ }^{46}$

Fourth, with regard to that same thesis Macpherson has ST§119-22 asserting that express consent is exclusively for the propertied, while tacit consent is for the poor. If anything, however, property-holding in these passages is linked by Locke to tacit consent. Moreover, Macpherson inexplicably confuses Locke's assertion that consent requires allowing one's

${ }^{44}$ Waldron, God, Locke, and Equality, 87-106.

${ }^{45}$ Ryan, 'Dictatorship of the Bourgeoisie', 226; Viner, 'Original Sin', 555; Tully, Discourse, 60-67, 112-16.

${ }^{46}$ Ashcraft, Locke's Two Treatises of Government, 173; Richard Ashcraft, 'Simple Objections and Complex Reality: Theorizing Political Radicalism in Seventeenth-Century England', Political Studies 40 (1992) 99-115, 106; Karen Vaughn, 'John Locke's Theory of Property: Problems of Interpretation', Literature of Liberty 3 (1980) 12-39, 29-30; Bertram Morris, 'Possessive Individualism and Political Realities', Ethics 75 (1965) 207-14, 213; Berlin, 'Professor Macpherson’, 466. 
property to be regulated by the polity with the proposition that only property-holders can perform consent. $^{47}$

\footnotetext{
${ }^{47}$ Dunn, Political Thought, 134-35; G. den Hartogh, 'Express Consent and Full Membership in Locke', Political Studies 38 (1990) 105-15; Ashcraft, Locke's Two Treatises of Government, 180-82.
} 